\title{
Fumonisins in Serbian Corn: Long-time Assessment under Actual Climate Change Conditions
}

\author{
S. JAKŠIĆ ${ }^{1 *}$, M. ŽIVKOV-BALOŠ ${ }^{1}$ I. JAJIĆ ${ }^{2}$ and B. ABRAMOVIĆ ${ }^{3}$ \\ ${ }^{1}$ Scientific Veterinary Institute "Novi Sad”, Rumenački put 20, 21000 Novi Sad, Serbia \\ ${ }^{2}$ University of Novi Sad, Faculty of Agriculture, Department of Animal Science, \\ Trg Dositeja Obradovića 8, 21000 Novi Sad, Serbia \\ ${ }^{3}$ University of Novi Sad, Faculty of Science, Department of Chemistry, \\ Biochemistry and Environmental Protection, Trg Dositeja Obradovića 3, 21000 Novi Sad, Serbia \\ (Received 22 February 2019; Accepted 12 September 2019; \\ Communicated by Á. Mesterházy)
}

Maize samples collected in Serbia during a period of seven years were investigated on the presence of fumonisins. Concentration of fumonisins was determined by validated direct competitive Enzyme Linked Immunosorbent Assay method. This method was in accordance with European Union requirements, therefore accredited and performed in the Serbian accredited official laboratory. Summary analysis of all obtained results revealed fumonisins contamination in $82 \%$ of the total of 291 maize samples with average contamination being $1.515 \mathrm{mg} / \mathrm{kg}$. An increase in the percentage of contaminated samples (from 51 to 100\%), as well as an increase in mean fumonisin concentration in positive samples (from 0.227 to $3.281 \mathrm{mg} / \mathrm{kg}$ ) and median values in positive samples (from 0.070 to $2.140 \mathrm{mg} / \mathrm{kg}$ ) was noticed during the observation period. Although in Serbia there is no regular control of fumonisins in corn for animal feeding, long-term results indicate their wide distribution in this grain. Since the data on climate elements show change in temperature and precipitation in relation to multiannual average on the territory of Serbia, further research on the effects of climate change on the development of mold, the appearance of insects and the production of toxins are necessary in order to check the resistance of currently grown hybrids in the territory of Serbia on fungal growth and fumonisins production.

Keywords maize, fumonisins, climate change, Serbia

Abbreviations: FUMs - fumonisins; FAO - Food and Agriculture Organization of the United Nations; WHO - World Health Organization; IARC - International Agency for Research on Cancer; EC - European Commission; ELISA - Enzyme Linked Immunosorbent Assay; RHSS - Republic Hydrometeorological Service of Serbia

\section{Introduction}

Fumonisins (FUMs) are mycotoxins known as common contaminant of cereals, mostly maize and maize-based products (FAO/WHO 2011). FUMs are primarily produced by molds of the genus Fusarium, FUMs B series being the most prevalent members of a family of toxins, which are directly associated with a range of pathogenic effects. Since

*Corresponding author; E-mail: sandra@niv.ns.ac.rs; Phone: +381214895363; Fax: +38121518544 
the presence of FUMs in maize has been statistically linked with cases of human esophageal carcinoma in South Africa and China, International Agency for Research on Cancer categorized Fusarium moniliforme toxins as potentially carcinogenic for humans (agents of the class 2B), similar to the ochratoxin A (IARC 2002).

The presence of FUMs in raw maize is determined by climatic conditions before and during harvest as well as by storage conditions. Investigations of the effects of diverse factors revealed that FUMs production are predominantly influenced by geographic locality and weather conditions (daily precipitation, maximum and minimum daily temperatures, relative humidity), insects, and, finally, by the maize hybrid itself (De la Campa et al. 2005). Global monitoring data on FUMs content in maize point out the importance of identifying their presence and emphasize the risks from toxicity of these mycotoxins (FAO/WHO 2011).

Before imposing the European Regulation (EC 2006a; 2007), only several countries had relevant national legislation on maximum permitted FUM levels. Subsequently, regulations on diverse contaminants including mycotoxins as well as FUMs have been published in the Official Journal of the European Union (EU). Thus, maximum permitted levels of particular contaminants in food have been laid down in the Commission Regulation No 1126/2007 (EC 2007) was adopted amending Regulation No 1881/2006 as regards Fusarium toxins in maize and maize products. Maximum permitted FUM contents in maize and maize-based products for human nutrition in Serbia (Serbian Regulation 2010; 2014a) are harmonized with EU Regulation. The recommendation of European Commission of August 17, 2006 (EC 2006a) encompasses maximum recommended values for deoxynivalenole, zearalenone, ochratoxin $A$, fumonisin $B_{1}$, and fumonisin $B_{2}$ in feed. The Regulation on the amendment of the Regulation on the quality of feed (Serbian Regulation 2014b) partly harmonizes the legislation in this field with the EU; however, FUMs have still not been included.

In spite the fact that maize is the most prevalent grain crop produced in Serbia because of favorable climatic conditions and fertile soil (Table 1) and is mainly used for animal feeding, maximum permitted FUM levels have been not prescribed for neither maize used for animal feeding nor in feed-mixtures. Almost the half of the total maize production in Serbia originates from individual producers, who face the problem of both somewhat lower yield and appropriate drying and storage, that is, adequate protection of the quality of harvested maize in view of mycological and mycotoxicological contamination. In spite of abundant reports on the presence of FUMs in maize and wheat (Jakšić et al. 2012; Kos et al. 2014), as well as frequent isolation of molds of the genus Fusarium and other

Table 1. Maize production in Serbia (average 2005-2014)

\begin{tabular}{|l|c|c|c|}
\hline \multirow{2}{*}{} & \multicolumn{3}{|c|}{ Maize } \\
\cline { 2 - 4 } & Area harvested (ha) & Production (t) & Yield per ha (t) \\
\hline Republic of Serbia & $1,157,677$ & $6,059,670$ & 5.2 \\
\hline Vojvodina & 651,188 & $3,924,337$ & 6.3 \\
\hline
\end{tabular}

Source: Statistic Office of the Republic of Serbia 2014. 
fusarium mycotoxins from grains and feed samples (Jajić et al. 2008), the presence of FUMs in feed is mostly not subject to control in Serbia because of the lack of relevant legislation.

Considering that FUMs in feed have not been addressed in Serbian legislative, while regulation of their contents in food for human consumption has been laid down as late as 2010, the information on grain-crops (especially maize) contamination with these mycotoxins is still very scant. In that respect, there is a critical need for investigating the presence and contents of FUMs in Serbia. The analysis of large number of samples was performed with an aim of obtaining a more realistic insight in the occurrence of this mycotoxin in maize. Having in mind that FUMs are common contaminants of maize, more precise understanding of environmental conditions favoring FUMs accumulation in maize grain is indispensable. Thus, the objective of this study was the long-term investigation of the FUMs concentration in maize during the production years characteristic by change of climatic factors in relation to the long-term average in Serbia.

\section{Materials and Methods}

\section{Samples and sampling}

Maize samples analyzed for FUM contents are collected in the period 2005-2014, immediately after harvest, as well as upon storage. The samples mainly originated from different localities in Vojvodina Province, but also from other regions of the Republic of Serbia. The sampling was performed directly on the field, after harvesting and immediately before storage in the silos (from September 1 to November 1), and these samples are labeled with B. Samples that were sampled after storage were collected between November 1 and September 1 of the following calendar year, and are marked with A.

\section{Sample preparation and analytical method}

Immediately upon sampling, $1000 \mathrm{~g}$ of each sample was prepared by grinding in a laboratory mill in such a way that $>93 \%$ passes through a $0.8 \mathrm{~mm}$ sieve. The samples were than homogenized by mixing, packed in plastic bags and stored at $-20{ }^{\circ} \mathrm{C}$, and allowed to reach room temperature prior to analysis.

Determination of total FUMs level using ELISA method was performed applying ELISA Ridascreen ${ }^{\circledR}$ Fumonisin R3401 kits (R-Biopharm, Darmstadt, Germany). The analytical quality of the ELISA method was assured by the use of certified reference materials as well as by participation in interlaboratory studies. For validation and analytical quality of the ELISA method, there were used naturally contaminated maize reference materials with certified FUMs content of $0.7 \pm 0.1 \mathrm{mg} / \mathrm{kg}$ and $4.0 \pm 0.1 \mathrm{mg} / \mathrm{kg}$ (TR-F100, lot \#F-C439, and lot \#F-C-441, Trilogy Analytical Laboratory, Washington, USA). The validation parameters were calculated, and their values were in accordance with recommendations given in EU Regulation 2006/401 (EC 2006b). Laboratory limit of detection was 0.025 $\mathrm{mg} / \mathrm{kg}$, and determination $0.050 \mathrm{mg} / \mathrm{kg}$. The limit of detection was determined by the 
series of 6 repeated blind probe measurements and calculated as the sum of the average value of the blind probe and 3 standard deviations. Quantification limit was determined as the sum of the average value and 10 standard deviations. Relative standard deviation calculated under repeatability was $8 \%$, while relative standard deviation calculated under reproducibility conditions was $10 \%$. The recovery rate was $99 \%$. Furthermore, the analytical quality of the ELISA method was assured by participation in proficiency testing scheme (Central Institute for Supervising and Testing in Agriculture, Czech Republic, 2014).

\section{Statistics}

Statistical analysis was performed using the PAST software package, version 3.25, Oslo, Norway. Statistical data analysis included the following: univariate analysis (descriptive statistics), and two sample $t$-test (unequal variances).

\section{Results}

\section{Fumonisin contents in maize in Serbia}

Presenting the long term data for all investigated samples is the best way to provide insights on FUMs contamination of maize in Serbia. The results of our analysis of FUM contents in 2005-harvest maize as well as for the period 2009-2014 are displayed in Table 2.

Presented results revealed that in only 16 out of 291 analyzed samples of raw maize concentration of FUMs exceeded maximum permitted levels $(4 \mathrm{mg} / \mathrm{kg})$ laid down in relevant regulations for human consumption (Serbian Regulation 2014a; EC 2007). It is to be emphasized that all samples analyzed in the framework of this investigation were intended for feed. Given that maximum permitted level of FUMs in maize for animal feeding are pretty high, being $60 \mathrm{mg} / \mathrm{kg}$, all investigated samples were in accordance with EU recommendations (EC 2006a). However, the maximum levels for certain species of animals are more stringent. That is how in feedingstuffs for pig, horses, rabits and pets limit is $5 \mathrm{mg} / \mathrm{kg}$, for fish $10 \mathrm{mg} / \mathrm{kg}$, for poultry, calves, lambs and kids it is $20 \mathrm{mg} / \mathrm{kg}$, while adult ruminants and mink have high tolerance, to even $50 \mathrm{mg} / \mathrm{kg}$. Although the tolerable level of fumonisin in corn is high, given its significant participation in mixtures, there is a risk of contamination of complete feed (Jakšić et al. 2018). The amounts of $5 \mathrm{mg} / \mathrm{kg}$ can cause pulmonary edema (Dilkin, 2010), however, the impact of low FUMs concentrations in feed on pig health should not be neglected. Pigs are very sensitive to FUM, and it should be considered the effects of chronic exposure to such low dietary levels. Exposure to an average concentration of FUMs in naturally contaminated feed had no effect on pig health but did affect the digestive microbiota balance, with Salmonella exposure amplifying this phenomenon (Burel et al. 2013). In addition to the negative impact on pig health, feed contaminated with FUMs has an impact on economic losses. More than $0.1 \mathrm{mg} / \mathrm{kg}$ FUMs in feed had affect on lower weght gain, while concentrations from $1 \mathrm{mg} / \mathrm{kg}$ of toxin have negative impact on meat quality (Rotter et al. 1994). 


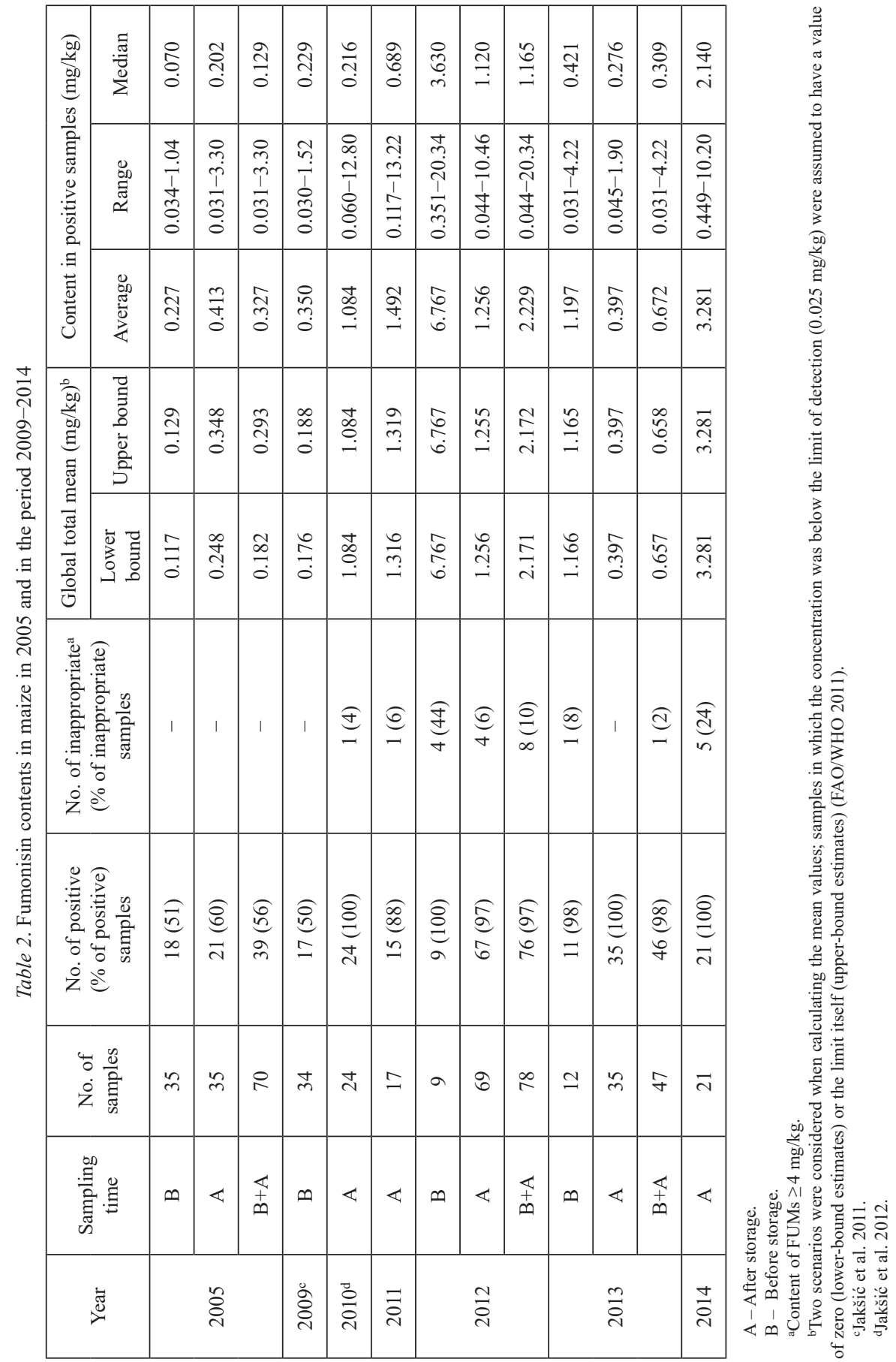


Analyzing the number of samples in which FUMs were detected, an increase in the percentage of contaminated samples (from 51 to 100\%) was noticed during the observation period. Also, an increase in mean FUM concentration in positive samples (from 0.227 to $3.281 \mathrm{mg} / \mathrm{kg}$ ) as well as median values in positive samples (from 0.070 to 2.140 $\mathrm{mg} / \mathrm{kg}$ ) can be observed, with the exception of 2013. These differences are conditioned by agro-meteorological conditions, and it should also be taken into account that some samples came from regular control and some were associated with certain animal health problems. Differences in measured concentrations of toxins in samples before and after storage were tested by using the Welch's $t$-test, since the population variances are unequal. The results of the statistical analysis showed that there was no significant difference in the concentration of FUMs in the samples before and after storage. For all three observed production years $(2005,2012$, and 2013), there was no significant difference at the 0.05 level. As already noted, the weather has effect on the production of fumonisins in maize on field. This research did not include a detailed climate analysis of each locality from which the samples came. However, since the samples originate from a relatively small geographical area, we analyzed the general change in climate elements and agrometeorological data provided by Republic Hydrometeorological Service of Serbia (RHSS) for the analyzed production years on territory of Serbia (Table 3).

It can be seen that during the observed period there were production years with an important changes in temperature and precipitation compared to the perennial average. However, given the observed time period, we can discuss about the impact of environmental factors and the response of corn hybrids on the potential conditions of contamination by mold and toxins, rather than on climate change. Certainly, this research will be a

Table 3. Pronounced changes in climatic factors relative to the perennial average (1961-1990)

in Serbia during the observed period (RHSS 2004-2014)

\begin{tabular}{|c|l|c|c|l|}
\hline Year & $\begin{array}{c}\text { General } \\
\text { characteristic of } \\
\text { vegetation period }\end{array}$ & $\begin{array}{c}\text { Deviation of the } \\
\text { mean annual } \\
\text { temperature }\end{array}$ & $\begin{array}{c}\text { Deviation of the mean } \\
\text { precipitation during } \\
\text { the growing season }\end{array}$ & \multicolumn{1}{|c|}{ Impact on agricultural production } \\
\hline 2005 & Humid & $+0.3^{\circ} \mathrm{C}$ & $+20 \%$ & $\begin{array}{l}\text { Favorable conditions for growth and } \\
\text { maturation }\end{array}$ \\
\hline 2009 & Average & $+1.0-1.4^{\circ} \mathrm{C}$ & $+10 \%$ & $\begin{array}{l}\text { Interfering corn silking, and pollen } \\
\text { dusting }\end{array}$ \\
\hline 2010 & $\begin{array}{l}\text { Warm and } \\
\text { humid }\end{array}$ & $+1.2^{\circ} \mathrm{C}$ & $+40 \%$ & $\begin{array}{l}\text { Negative impact of precipitation } \\
\text { surplus }\end{array}$ \\
\hline 2011 & Warm and dry & $+1.2^{\circ} \mathrm{C}$ & $-17 \%$ & $\begin{array}{l}\text { Lower quality, lower yield, higher } \\
\text { activity of plant pests }\end{array}$ \\
\hline 2012 & Extreme dry & $+1.0-1.4^{\circ} \mathrm{C}$ & $-75 \%$ & $\begin{array}{l}\text { Lower quality, lower yield, higher } \\
\text { activity of plant pests, Fusarium } \\
\text { infection }\end{array}$ \\
\hline 2014 & $\begin{array}{l}\text { Warm and } \\
\text { extreme humid }\end{array}$ & $+1.8^{\circ} \mathrm{C}$ & $+100-200 \%$ & $\begin{array}{l}\text { Lower quality, higher activity of plant } \\
\text { pests }\end{array}$ \\
\hline
\end{tabular}


contribution to the analysis of climate change after a longer period of time. In addition, a large influence on the contamination has grown on different maize hybrids. Different resistance of cultivated hybrids to toxin producing fungi (Krnjaja et al. 2016) is an additional cause of differences in FUMs contamination. However, the increase of the resistance level will surely lessen the environmental effect, so resistance stabilizes low fumonisin concentration better than any other mean. An effective control of insect damage is also inevitable.

\section{Discussion}

As aforementioned, there are not many reports on investigation either of FUMs or FB1 content in maize in Serbia. Stanković et al. (2011) detected FUMs in 70.7\% of 203 analyzed maize samples in the period 2007-2009. The concentration of $\mathrm{FB}_{1}$ varied within a range $0.75-4.9 \mathrm{mg} / \mathrm{kg}$ with an average value $1.226 \mathrm{mg} / \mathrm{kg}$. The authors suggested that variations in FUM contents are due to different resistance of the plants as well as stress conditions associated with drought and insect attacks during investigation period. Namely, the highest prevalence of positive samples (80.1\%) was recorded in 2007 characterized by high temperatures and draught. Kos et al. (2014) established contamination of FUMs ranging from 0.500 to $3.020 \mathrm{mg} / \mathrm{kg}$ in all 90 analyzed samples of 2012-harvest maize. The authors concluded that production of FUMs was favored by hot and dry weather conditions. Similar researches were conducted in our neighboring countries, e.g. Croatia, Hungary, Romania, and Bulgaria. The data from 1992 revealed FUMs contamination in Croatia $\left(58 \%\right.$ positive for $\mathrm{FB} 1$ and $21 \%$ for $\mathrm{FB}_{2}$ ), and Romania $\left(50 \%\right.$ positive for $\mathrm{FB}_{1}$ and $17 \%$ for $\mathrm{FB}_{2}$ ) (Doko et al. 1995). However, the reported FUM contents were lower as compared with those obtained in Serbia, as indicated above. Namely, the average $\mathrm{FB}_{1}$ levels in positive samples in Croatia were $0.020 \mathrm{mg} / \mathrm{kg}$ (range $0.010-0.060 \mathrm{mg} / \mathrm{kg}$ ) and in Romania $0.010 \mathrm{mg} / \mathrm{kg}$ (range $0.010-0.020 \mathrm{mg} / \mathrm{kg}$ ), whereas $\mathrm{FB}_{2}$ content was the same in both countries being $0.010 \mathrm{mg} / \mathrm{kg}$. However, according to the reports of Jurjević et al. (1999) and Domijan et al. (2005) the frequency of FUMs contamination $\left(\mathrm{FB}_{1}+\mathrm{FB}_{2}\right)$ in 1996, 1997, and 2002 in Croatia was significantly higher, being 99\%, 93\%, and 100\%, respectively. The average contents of total FUMs in positive samples from 1996, 1997, and 2002 were $0.645,0.134$, and $0.460 \mathrm{mg} / \mathrm{kg} \mathrm{FB}$, respectively, whilst three of 49 investigated samples were positive for $\mathrm{FB}_{2}$ at concentrations $0.068,0.109$, and $3.084 \mathrm{mg} / \mathrm{kg}$. According to maize analysis from 2007 (Šegvić Klarić et al. 2009), the presence of FUMs was confirmed in $27 \%$ samples, with average concentration of $3.690 \mathrm{mg} / \mathrm{kg}$. In 1997, in maize products analyzed in Hungary (Varga et al. 2004), FUMs were detected in $67 \%$ samples yet with the very low contamination levels $(0.016-0.058 \mathrm{mg} / \mathrm{kg})$. The analysis of maize for FUMs contamination was performed in Bulgaria considering the climatic conditions (Manova and Mladenova 2009), and FUMs were detected in $94.7 \%$ of samples ranging between 0.249 and $4.050 \mathrm{mg} / \mathrm{kg}$. According to the data from $2001,50 \%$ of samples contained 0.03-6.56 mg/kg FUMs (Vrabcheva et al. 2002). The investigation of the presence of fusarium mycotoxins in cereals in Croatia performed by Pleadin et al. (2013) revealed that maize was the most contaminated cereal, and the highest percentage of all 
analyzed cereal samples was contaminated with deoxynivalenol followed by zearalenone, FUMs, and T2. However, the highest percentage of maize samples was contaminated with FUMs (90\%) at average concentration of $1.756 \mathrm{mg} / \mathrm{kg}$. All samples were 2011-harvest, a year characterized by warm and dry weather as compared to 2010 (90\% positive samples with average concentration $4.509 \mathrm{mg} / \mathrm{kg}$ ) characterized by cold and humid weather conditions. Thus, the authors attribute generally lower FUMs production in 2011 to the climatic conditions (Pleadin et al. 2012). There are many different studies on FUMs in maize worldwide. Italy and Brazil, as significant producers of maize, with a climate conducive to FUM production, pays considerable attention to control. Recent data show concentrations comparable to our research. In Brazil, 0.4 to $9.1 \mathrm{mg} / \mathrm{kg}$ were measured in maize in 2012 (Silva et al. 2017), and in Italy between 2006 and 2008, mean values at different locations were from 4.8 to $10.9 \mathrm{mg} / \mathrm{kg}$ (Berardo et al. 2011). On the other hand, data from USA show significantly higher contamination than in Europe, and an average concentration of $37.97 \mathrm{mg} / \mathrm{kg}$ was measured in Arkansas (Abbas et al. 2006).

The results (Table 2) were compared with the results presented in studies of FAO/ WHO (2011) obtained by summarizing the results of global analysis of 7,060 samples. The percentage of positive samples in Serbia (according to our investigation) was higher being $85 \%$ as compared to $76 \%$. However, the average FUMs concentration in Serbia is lower $(1.262 \mathrm{mg} / \mathrm{kg}$ as compared to $1.625 \mathrm{mg} / \mathrm{kg}$, when considering upper limit). According to the presented review of global occurrence of FUMs, it is obvious that climatic conditions are greatly responsible for the formation of Fusarium monilifome and F. proliferatum, and hence the occurrence of FUMs in maize. Variations in the levels of maize contamination are likely to be associated with agricultural factors and, partly, with variable sensitivity of particular crops to Fusarium species interrelated with climatic conditions. Besides, the applied methods for FUMs analysis should be taken into consideration given the differences in detection limits for particular techniques and hence different results on the percentage of contaminated samples.

The obtained results indicated high incidence of FUMs contamination of maize samples, yet with low concentrations. By analyzing the concentration of FUMs in the samples before and after storage, we concluded that storage had no significant effect on the production of toxins. Comparative analysis of FUMs content and agro-meteorological conditions throughout the research period suggests the necessity of further examination of interconnection of climatic conditions and mycotoxicological safety of maize in the territory of Serbia. The obtained results could be the starting point in developing prognostic model for predicting the risks of mycotoxin contamination in Serbia. These results strongly emphasize the mandatory continuous monitoring of FUMs and establishment of relevant database on their presence under climatic conditions in Serbia with an aim of obtaining relevant data for predicting contamination of FUMs. Further research and analysis of the effects of particular hybrids and applied preventive agrotechnical and agrochemical measures under production conditions in Serbia are required. The obtained results strongly indicate the necessity of preparing the draft on harmonization of legislation on FUMs contents in feed in Serbia with the relevant EU regulations. 


\section{Acknowledgements}

The work was supported by the Ministry of Education, Science and Technological Development of the Republic of Serbia (Project No 172042).

\section{References}

Abbas, H.K., Cartwright, R.D., Xie, W., Thomas Shier, W. 2006. Aflatoxin and fumonisin contamination of corn (maize, Zea mays) hybrids in Arkansas. Crop Prot., 25:1-9.

Berardo, N., Lanzanova, C., Locatelli, S., Langanà, P., Verderio, A., Motto, M. 2011. Levels of total fumonisins in maize samples from Italy during 2006-2008. Food Addit. Contam. B, 4:116-124.

Burel, C., Tanguy, M., Guerre, P., Boilletot, E., Cariolet, R., Queguiner, M., Postollec, G., Pinton P., Salvat, G., Oswald, I., Fravalo, P. 2013. Effect of low dose of fumonisins on pig health: immune status, intestinal microbiota and sensitivity to Salmonella. Toxins (Basel), 5:841-864.

De la Campa, R., Hooker, D.C., Miller, J.D., Schaafsma, A.W., Hammond, B.G. 2005. Modeling effects of environment, insect damage, and $B t$ genotypes on fumonisin accumulation in maize in Argentina and the Philippines. Mycopathologia 159:539-552.

Dilkin, P., Direito, G., Simas, M.M.S., Mallmann, C.A., Correa, B. 2010. Toxicokinetics and toxicological effects of single oral dose of fumonisin B1 containing Fusarium verticillioides culture material in weaned piglets. Chem.-Biol. Interact. 185:157-162.

Doko, M.B., Rapior, S., Visconti, A., Schjøth, J.E. 1995. Incidence and levels of fumonisin contamination in maize genotypes grown in Europe and Africa. J. Agric. Food Chem. 43:429-434.

Domijan, A., Peraica, M., Jurjević, Ž., Ivić, D., Cvjetković, B. 2005. Fumonisin $B_{1}$, fumonisin $B_{2}$, zearalenone and ochratoxin A contamination of maize in Croatia. Food Addit. Contam. 22:677-680.

EC, Commission Recommendation 576/2006. OJEU L229 August 2006a.

EC, Commission Regulation 401/2006. OJEU L70 February 2006b.

EC, Commission Regulation 1126/2007 OJEU L255 September 2007.

FAO/WHO - World Health Organization 2011. Evaluation of Certain Food Additives and Contaminants. Seventy-forth report of the Joint FAO/WHO Expert Committee on Food Additives. WHO Technical Report Series 966.

IARC International Agency for Research on Cancer 2002. IARC Monographs on the Evaluation of Carcinogenic Risks to Humans, Vol. 82.

Jajić, I., Jurić, V., Glamočić, D., Abramović, B. 2008. Occurrence of deoxynivalenol in maize and wheat in Serbia. Int. J. Mol. Sci. 9:2114-2126.

Jakšić, S., Prunić, B., Milanov, D., Jajić, I., Bjelica, L., Abramović, B. 2011. Fumonisins and co-occurring mycotoxins in north Serbian corn. J. Nat. Sci. Matica Srpska Novi Sad 120:49-59.

Jakšić, S., Abramović, B., Jajić, I., Živkov-Baloš, M., Mihaljev, Ž., Despotović, V. 2012. Co-occurrence of fumonisins and deoxynivalenol in wheat and maize harvested in Serbia. Bull. Environ. Contam. Toxicol. 89:615-619.

Jakšić, S., Popov, N., Živkov Baloš, M., Prodanov-Radulović, J., Abramović, B. 2018. Fumonisins in pig feed. Arh. Vet. Med. 11:43-51,

Jurjević, Ž., Solfrizzo, M., Cvjetković, B., Avantaggiato, G., Visconti, A. 1999. Ochratoxin A and fumonisins $\left(\mathrm{B}_{1}\right.$ and $\left.\mathrm{B}_{2}\right)$ in maize from Balcan nephropathy endemic and non endemic areas of Croatia. Mycotoxin Res. 15:67-80.

Kos, J., Janić Hajnal, E., Škrinjar, M., Mišan, A., Mandić, A., Jovanov, P., Milovanović, I. 2014. Presence of Fusarium toxins in maize from Autonomous Province of Vojvodina, Serbia. Food Control 46:98-101.

Krnjaja, V., Stanković, S., Obradović, A., Mandić, V., Bijelić, Z., Vasić, T., Jauković, M. 2016. Fungal and mycotoxin contamination of maize hybrids in different maturity groups. Biotech. Anim. Husb. 32:71-81.

Manova, R., Mladenova, R. 2009. Incidence of zearalenone and fumonisins in Bulgarian cereal production. Food Control 20:362-365. 
Pleadin, J., Perši, N., Mitak, M., Zadravec, M., Sokolović, M., Vulić, A. 2012. The natural occurrence of T2 toxin and fumonisins in maize samples in Croatia. Bull. Environ. Contam. Toxicol. 88:863-866.

Pleadin, J., Vahčič, N., Perši, N., Ševelj, D., Markov, K., Frece, J. 2013. Fusarium mycotoxins occurrence in cereals harvested from Croatian fields. Food Control 32:49-54.

Republic Hydrometeorological Service of Serbia (RHSS) 2004-2014. Agro-meteorological conditions in the 2004/2005; 2008/2009; 2009/2010; 2010/2011; 2011/2012; 2012/2013; 2013/2014 years in the territory in the Republic of Serbia. http://www.hidmet.gov.rs/ciril/meteorologija/agrometeorologija.php, Accessed 5 September 2018.

Rotter, B.A., Thompson, B.K., Lessard, M., Trenholm, H.L., Tryphonas, H. 1994. Influence of low level exposure of fusarium mycotoxins on selected immunological and hematological parameters in young swine. Fund. Appl. Toxicol. 23:117-124.

Serbian Regulation 2010. Sl glasnik RS 45/10, 1-74.

Serbian Regulation 2014a. Sl glasnik RS 29/14, 1-27.

Serbian Regulation 2014b. Sl glasnik RS 27/14, 1-14.

Silva, J.J., Viaro, H.P., Ferranti, L.S., Oliveira, A.L.M., Ferreira, J.M., Ruas, C.F., Ono, E.Y.S., Fungaro, M.H.P. 2017. Genetic structure of Fusarium verticillioides populations and occurrence of fumonisins in maize grown in Southern Brazil. Crop Prot. 99:160-167.

Stanković, S., Lević, J., Krnjaja, V. 2011. Fumonisin B 1n $_{\text {in }}$ maize, wheat and barley grain in Serbia. Biotechnol. Anim. Husb. 27:631-641.

Statistical Office of the Republic of Serbia 2014. Statistical Yearbook of the Rebublic of Serbia.

Šegvić Klarić, M., Cvetnić, Z., Pepeljnjak, S., Kosalec, I. 2009. Co-occurrence of aflatoxins, ochratoxin A, fumonisins, and zearalenone in cereals and feed, determined by competitive direct enzyme-linked immunosorbent assay and thin-layer chromatography. Arh. Hig. Rada Toksikol. 60:427-434.

Varga, J., Toth, B., Mesterhazy, A., Teren, J., Fazekas, B. 2004. Hugary mycotoxigenic fungi and mycotoxins in foods and feeds in Hungary. In: Logrieco, A., Visconti, A. (eds) An overview on toxigenic fungi and mycotoxins in Europe, Springer.

Vrabcheva, T., Stroka, J., Anklam, E. 2002. Occurrence of fumonisin B1 in Bulgarian maize samples determined by ELISA and TLC methods using different clean up steps. Mycotoxin Res. 18:46-56. 